Jurnal Pendidikan Anak Usia Dini

ISSN 2301-9905

Volume 9, No. 2, Januari 2019

Fakultas Keguruan dan Ilmu Pendidikan- Universitas Muhammadiyah Tangerang

\title{
Dampak Penggunaan Gadget Terhadap Komunikasi Anak Usia 4-5 Tahun
}

\author{
${ }^{1}$ Sari Noorhayati, ${ }^{2}$ Nurul Fitria Kumala Dewi \\ 1,2 Program Studi Pendidikan Guru Pendidikan Anak Usia Dini ; Fakultas \\ Keguruan Dan Ilmu Pendidikan ; Universitas Muhammadiyah Tangerang \\ e-mail : $\underline{\text { Nutysari04@gmail.com, } \underline{2} \text { nurulfitriakd@gmail.com }}$
}

\begin{abstract}
Abstrak
Penelitian ini bertujuan untuk mengetahui dampak penggunaan gadget anak usia 4-5 tahun. Kemampuan komunikasi atau berbicara anak usia 4-5 tahun adalah anak mampu menyampaikan informasi, mengutarakannya kepada orang lain, berpartisipasi dalam percakapan, memahami informasi, menyimak perkataan orang lain dan memahami cerita yang di bacakan. Akan tetapi pada sumber data yang peneliti dapatkan kemampuan komunikasi atau berbicara anak masih rendah, anak belum dapat mengucapkan beberapa kata dengan jelas dan pola komunikasi yang digunakan cenderung diam hanya dengan gerakan saja. Penelitian ini termasuk jenis penelitian kualitatif deskriptif yang mengacu kepada hasil observasi dan wawancara. Pada penelitian ini digunakan dua sumber data yaitu IFA dan FYN. Hasil data disajikan secara narasi deskriptif. Hasil penelitian menunjukkan bahwa penggunaan gadget berdampak pada kemampuan komunikasi atau berbicara anak usia 4-5 tahun. Berdasarkan hasil temuan peneliti yang didapatkan, maka peneliti ini layak digunakan oleh masyarakat luas dan dapat dikembangkan untuk penelitian yang lebih lanjut.
\end{abstract}

Kata kunci : Gadget, Kemampuan komunikasi atau berbicara, Anak usia dini

\section{Pengantar}

Anak usia dini pada hakikatnya merupakan individu yang memiliki pola pertumbuhan dan perkembangan dalam aspek fisik, kognitif, sosial emosional, kreativitas, bahasa, komunikasi khusus dan sesuai dengan tahapan yang sedang dilalui oleh anak tersebut. Pendidikan Anak Usia Dini bertujuan untuk mengembangkan seluruh potensi anak kelak dapat berfungsi sebagai manusia utuh sesuai falsafah suatu bangsa. Anak dapat dipandang sebagai individu yang baru mulai mengenal dunia. Ia belum mengetahui tata krama, sopan santun, aturan, norma, etika, dan berbagai hal tentang dunia. Ia juga sedang belajar berkomunikasi dengan orang lain dan belajar memahami orang lain. Anak perlu 
dibimbing agar mampu memahami berbagai hal tentang dunia beserta isinya (Suyanto, 2005, h. 3).

Menurut Jamaris (2006), karakteristik kemampuan anak usia dini 4 tahun yaitu: 1). Terjadi perkembangan yang cepat dalam kemampuan bahasa anak. Anak dapat menggunakan kalimat dengan baik dan benar. 2). Menguasai 90 persen dari fonem dan sintaksis bahasa yang digunakannya. 3). Dapat berpartisipasi dalam suatu percakapan. Anak sudah dapat mendengarkan orang lain berbicara dan menanggapi pembicaraan tersebut (Susanto, 2011, h.78).

Anak usia dini tidak semua komunikasi dengan bicara, bahkan dengan tangisan anak, gestur anak juga termasuk komunikasi. Pada saat anak sedang bermain, anak seringkali berbicara dengan dirinya sendiri atau dengan mainannya. Meskipun demikian, pada saat minat untuk menjadi bagian dari kelompok sosial berkembang, mereka sebagian besar bicara untuk berkomunikasi dengan yang lain dan hanya sewaktu waktu berbicara terhadap diri mereka dan terhadap mainan mereka.

Menurut (Warisyah, 2015) Gadget merupakan alat elektronik yang digunakan sebagai media informasi, media belajar dan sebagai hiburan. Manfaat gadget lainnya yaitu dapat tersambung dengan internet. Siswa sekolah dasar sudah mengenal fungsi internet. Sehingga banyak siswa sekolah dasar yang menyalahgunakan penggunaan internet untuk hal negatif. Sehingga siswa harus selalu dalam pengawasan orang tua. Orang tua memberikan gadget pada anaknya dengan tujuan untuk mengenalkan games pada anaknya. Dibanding dengan orang desawa yang baru mengenal gadget, anak lebih cepat menguasai gadget daripada orang dewasa. Bahkan orang tua mereka belum tentu dapat mengoperasikan gadget yang mereka miliki (Rozalia, 2017, h. 724).

Penggunaan gadget dalam kurun waktu yang lama dapat berdampak pada perkembangan anak diantaranya (Santosa, 2015, h.5-13):

a. Perkembangan motorik. Perkembangan motorik menjadi sangat penting saat anak berusia balita. Anak usia balita memiliki tugas perkembangan yang perlu dicapainya dalam aspek motorik. Salah satunya adalah menulis namanya dengan baik dan benar (motorik halus), melempar, menendang, dan menangkap bola (motorik kasar). Perkembangan media dan teknologi berpengaruh terhadap 
perkembangan motorik halus anak. Sering kali guru sekolah atau orang tua mengeluh tulisan tangan anak yang kurang rapi, bahkan sulit dibaca.

b. Perkembangan fisik. Konsumsi media televisi dan gadget membuat anak betah betah berlama-lama di depan layar. Anak jadi enggan melakukan aktivitas fisik yang dapat mengakibatkan kegemukan dan obesitas. Seperti yang kita ketahui, obesitas tidak hanya berdampak pada proposi tubuh anak yang tidak sesuai dengan usianya, namun juga dapat menjadi sumber penyakit.

c. Perkembangan neurologi. Media teknologi sangat membantu dalam menstimulasi fungsi dan kerja otak anak. Banyaknya muatan informasi yang disediakan oleh media dan gadget diserap oleh otak dan direkam dalam memori anak. Menurut para ilmuwan, perkembangan saraf-saraf otak terbentuk sangat cepat sejak bayi hingga mencapai maksimum usia remaja 14 tahun.

Berdasarkan observasi peneliti di TK Bina Madani Tangerang, pada tanggal 28 Februari 2018, bahwa ditemukan adanya anak yang mengalami kesulitan dalam perkembangan bahasa terutama dalam aspek komunikasi/ berbicara. Anak yang pertama terlihat kesulitan ketika dia mengucapkan kata-kata, bahkan ketika ia ditanya terlihat sekali sulit meresponnya. Ketika merespon pun anak tersebut hanya mengucapkan 1 sampai 2 kata dengan artikulasi yang kurang jelas. Anak yang kedua, terlihat kesulitan menjawab pertanyaan sesuai dengan konteksnya bahkan kadang-kadang terselip kata-kata yang kurang baik.

Permasalah tersebut, peneliti mengambil kesimpulan bahwa seringnya penggunaan gadget pada anak usia dini akan berdampak sekali terhadap perkembangan bahasa anak terutama dalam aspek bicara/komunikasi.

\section{Metode}

Metode yang digunakan ini adalah metode kualitatif. menurut (Sugiyono, 2016, h.15) adalah metode penelitian berdasarkan pada filsafat postpositivisme, digunakan untuk meneliti pada kondisi obyek yang alamiah, (sebagai lawannya adalah eksperimen) dimana peneliti adalah sebagai instrumen kunci, pengambilan sempel sumber data dilakukan secara purposive dan snowbaal, teknik pengumpulan dengan trianggulasi (gabungan), analisis data 
bersifat induktif/kualitatif, dan hasil penelitian kualitatif lebih menekankan makna dari pada generalisasi.

Strauss \& Corbin (2007) menulis, istilah penelitian kualitatif dimaksudkan sebagai jenis penelitian yang temuan-temuannya tidak diperoleh melalui prosedur statistik atau bentuk hitungan lainnya. Contohnya dapat berupa penelitian tentang riwayat dan perilaku seseorang, di samping juga tentang peranan organisasi, pergerakan sosial, atau hubungan timbal balik. Sebagian datanya dapat dihitung sebagaimana data sensus, namun analisisnya bersifat kualitatif (Putra, dkk, 2013, h. 66).

Berdasarkan kesimpulan di atas bahwa metode penelitian kualitatif menggunakan dan mengandalkan data yang bersifat verbal yang rinci dan mendalam dalam beragam bentuknya, dan meggunakan cara dengan mendiskripsikan fakta kemudian disusun berdasarkan analisisnya.

\section{Hasil dan Pembahasan}

Penelitian ini dilakukan di TK Bina Madani Tangerang, pada kelompok usia 4-5 tahun, Penelitian dilakukan peneliti dengan melakukan observasi awal pada tanggal 28 Februari 2018, peneliti hadir sebagai pengamat berjalannya proses belajar mengajar dan tidak ikut campur langsung dalam proses belajar mengajar yang sedang berlangsung. Selama observasi awal, peneliti mulai menemukan adanya perbedaan cara anak dalam berkomunikasi, anak yang pertama komunikasi/berbicaranya tidak begitu jelas artikulasinya dan suka menucapkan bahasa yang ada dalam gadget, anak yang kedua lebih cenderung komunikasi dengan gerakan tubuhnya. Peneliti juga melakukan observasi kepada orang tua tentang penggunaan gadget dirumah dan komunikasi anak dirumah. Dari hasil observasi awal tersebut peneliti mengambil kesimpulan bahwa komunikasi orang tua mempunyai peran terhadap dampak penggunaan gadget anak. Peneliti melakukan penelitian selama 3 minggu dimana setiap minggu dilakukan 4 kali pertemuan. Subjek peneliti adalah 2 (dua) anak yang dijadikan sampel penelitian yang berumur 4-5 tahun. Hasil observasi dilakukan peneliti berdasarkan Indikator kemampuan komunikasi anak yang dilakukan pada anak selama di sekolah maupun di rumah.

Indiktor kemampuan komunikasi dalam hal ini yaitu 1. Menyampaikan Informasi yaitu a) Mengutarakan keinginan kepada orang lain, b) Menyebutkan kata-kata yang dikenal, c) Berpartisipasi dalam percakapan. 2. Memahami informasi yaitu a) Menyimak 
perkataan orang lain, b) Mengerti dua perintah, c) Memahami cerita yang dibacakan. 3. Gambar yaitu a) Membuat coretan bermakna, b) Mengenal simbol, c) Meniru/menuliskan huruf A-Z.

Pada sumber data yang pertama peneliti melakukan wawancara dengan guru IFA untuk mendapatkan informasi mengenai kemampuan komunikasi/berbicara IFA di sekolah. Saat peneliti melihat komunikasi IFA di sekolah IFA menggunakan bahasa isyarat seperti menggunakan 2 jarinya seakan-akan itu adalah pistol dan menembakkan ke arah temannya, setelah kegiatan selesai guru IFA menanyakan kepada murid "siapa yang hari ini sudah makan?" semua menjawab bersama-sama kecuali IFA yang hanya diam dan tidak menjawab apa-apa. Peneliti juga melihat komunikasi/berbicara IFA seperti kurang begitu jelas artikulasinya seperti "sapa papolisi" mungkin yang dimaksudkan IFA yaitu "ditembak pak polisi", dan beberapa kalimat-kalimat yang asing seperti yang ada di game nya "you lose, i win" juga bahasa-bahasa inggris lainnya yang kurang begitu jelas dan tidak ada artinya.

Pada sumber data yang kedua bernama FYN peneliti melakukan wawancara dengan guru FYN untuk mendapatkan informasi mengenai kemampuan komunikasi/bicara IFA di sekolah. Ketika FYN di ajak bicara, FYN lebih banyak mengeluarkan kata-kata negatif seperti "mampus" atau "bodoh" dan mengucapkan "apa lu? Mau gue tonjok?". Untuk menyampaikan suatu keinginan FYN sudah bisa namun terkadang dimana FYN tidak ingin berbicara bahkan untuk bercerita FYN masih belum berkembang.

1. Penggunaan gadget pada anak

a. Penggunaan gadget pada IFA

Setelah mendapatkan temuan penelitian mengenai penggunaan gadget pada anak peneliti observasi ke rumah IFA saat peneliti datang ke rumah IFA, IFA selalu membawa gadget di tangannya dimana pada saat menggunakan gadget IFA sedang bermain game tempur (CO I.4:4-6 h.91). Dan untuk waktu libur, biasanya ayah IFA mengajak IFA bermain game bersama dengan menggunakan PlayStation (CO I.3:6 h.87). Setiap IFA pulang sekolah selalu diberikan mainan yang ada di gadget tersebut (CO I.3:8 h.87). IFA bisa menghabiskan waktu bermain dengan gadget-nya sepulang sekolah dari jam 11.00-13.00, IFA akan berhenti bermain gadget ketika gadget-nya harus di charge, 
kemudian 1 jam kemudia IFA memainkan gadget-nya kembali. Kemudian pada malam hari jam 19.00 ketika ayah IFA pulang kerja, IFA berhenti menggunakan gadget-nya (CWS I.1:43-46 h.67). Aplikasi yang digunakan IFA saat menggunakan gadget yaitu game robox, stickman, battle simulator dan youtube, saat melihat youtube IFA hanya melihat game yang dia mainkan saja (CWS I.1:46-48 h.67). Ketika IFA sedang bermain gadget terkadang IFA jarang di dampingi orang tua, hanya saja sesekali hanya di lihat saja oleh ibunda IFA, karena IFA seharian bermain gadget (CWS I.1:50-51 h.67).

b. Penggunaan gadget pada FYN

Setelah mendapatkan temuan observasi pada anak yang kedua mengenai penggunaan gadget di rumah, peneliti mencoba mengunjungi rumah FYN dan menanyakan kegitan FYN di rumah. Pada saat peneliti datang, FYN sedang tidak bermain dengan gadget nya melainkan FYN sedang bermain dengan mainnya seperti mobil-mobilan (CO II.3:3-4 h.89). Dalam 1 hari FYN hanya menggunakan gadget 1 jam bahkan tidak sampai 1 jam, FYN menggunakan gadget ketika ada ayah saja, ibu FYN tidak memberikan FYN gagdet tapi terkadang FYN suka tiba-tiba mengambil HP ibunda nya untuk mengaji (CWS IV.1:42-44 h.73). Aplikasi yang digunakan FYN dalam gadget yaitu hanya meng-edit foto, melihat youtube kartun ice cream, pemadam kebakaran dan aplikasi untuk mengaji (CWS IV.1:45-47 h.73). FYN selalu didampingi orang tua ketika menggunakan gadget-nya (CWS IV.1:49 h.73).

2. Kemampuan komunikasi/berbicara anak di sekolah

Sekolah merupakan suatu lembaga pendidikan yang dirancang untuk pengajaran siswa atau murid di bawah pengawasan guru. Taman kanak-kanak merupakan wadah pendidikan prasekolah. Pendidikan prasekolah ini sangat penting bagi pembangunan mental psikis dan kemampuan bersosialisasi anak. Anak yang mendapatkan pendidikan prasekolah cenderung berhasil melewati setiap jenjang pendidikan formal.

Fungsi yang penting dalam pendidikan prasekolah diantaranya yaitu untuk mengembangkan seluruh kemampuan yang dimiliki anak sesuai dengan tahap perkembangannya agar dapat melakukan deteksi dini terhadap kemungkinan terjadinya gangguan dalam pertumbuhan dan perkembangan potensi-potensi yang dimiliki anak usia dini. 
Pada sumber data yang pertama peneliti melakukan wawancara dengan guru IFA untuk mendapatkan informasi mengenai kemampuan komunikasi/berbicara IFA di sekolah. Saat peneliti melihat komunikasi IFA di sekolah IFA menggunakan bahasa isyarat seperti menggunakan 2 jarinya seakan-akan itu adalah pistol dan menembakkan ke arah temannya, setelah kegiatan selesai guru IFA menanyakan kepada murid "siapa yang hari ini sudah makan?" semua menjawab bersama-sama kecuali IFA yang hanya diam dan tidak menjawab apa-apa (CO I.1:6-10 h.79). Peneliti juga melihat komunikasi/berbicara IFA seperti kurang begitu jelas artikulasinya seperti "sapa papolisi" mungkin yang dimaksudkan IFA yaitu "ditembak pak polisi", dan beberapa kalimat-kalimat yang asing seperti yang ada di game nya "you lose, i win" juga bahasa-bahasa inggris lainnya yang kurang begitu jelas dan tidak ada artinya (CO I.1:12-15 h.79). Untuk menginginkan suatu keinginan IFA terkadang IFA mengungkapkannya dengan emosi, jika di beri tahukan secara halus IFA akan marah (CWS III.1:7-10 h.70).

Pada sumber data yang kedua bernama FYN peneliti melakukan wawancara dengan guru FYN untuk mendapatkan informasi mengenai kemampuan komunikasi/bicara IFA di sekolah. Ketika FYN di ajak bicara, FYN lebih banyak mengeluarkan kata-kata negatif seperti "mampus" atau "bodoh" dan mengucapkan "apa lu? Mau gue tonjok?" (CO II.1:9-12 h.81). Untuk menyampaikan suatu keinginan FYN sudah bisa namun terkadang dimana FYN tidak ingin berbicara bahkan untuk bercerita FYN masih belum berkembang (CWS VI.1:9 h.76). FYN dapat mengutarakan sesuatu yang dia kenal, tapi jika ada sesuatu barang yang hilang di loker FYN dia tidak pernah cari atau bertanya kepada guru, FYN lebih cenderung cuek berbeda dengan anak yang lainnya jika ada sesuatu barang yang hilang pasti akan bertanya kepada guru, namun FYN sudah bisa menyebutkan kegiatan apa saja yang sudah dikerjakan (CWS VI.1:11-17 h.76). Untuk berinteraksi dengan orang lain FYN belum bisa berinteraksi dengan baik, terkadang FYN ingin berinteraksi dengan temannya dengan menggunakan bahasa kasar, dimulai dengan sesuatu yang negatif (CWS VI.1:18-22 h.76-77).

3. Kemampuan komunikasi/berbicara anak di rumah

Pada wawancara dengan ibu dan ayah IFA didapatkan bahwa kemampuan komunikasi/berbicara IFA masih minim (CO I.3:3-5 h.86). Jika IFA mempunyai suatu keinginan IFA sudah dapat mengungkapkannya, seperti minta di bikinkan indomie IFA 
bilang "mima aku mau indomie" atau "mima aku ga mau pake seragam" dimana saat itu IFA dan ibunya sedang pergi ke mall, ibu IFA berfikir bahwa IFA hanya bercanda saja, ternyata IFA memang tidak ingin memakai seragam sekolah ke mall, IFA hanya ngumpet di belakang ibu nya (CWS I.1:6-11 h.66). IFA juga sudah bisa menyebutkaan sesuatu yang dia kenal misalnya seperti IFA bisa menyebutkan benda disekitarnya, orang-orang di dekatnya serta hewan IFA sudah bisa menyebutkan semua (CWS I.1:12-14 h.66). Untuk berinteraksi dengan orang lain IFA harus dipancing terlebih dahulu untuk di ajak bicara, harus ibunda IFA yang memulai nya (CWS I.1:18-120 h.66).

Hasil wawancara dengan ibu dan ayah FYN didapatkan bahwa kemampuan komunikasi/berbicara FYN di rumah sudah mulai berkembang dengan baik. Jika FYN mempunyai suatu keinginan FYN akan mengungkapkannya seperti misalnya FYN minta jalan-jalan ke outbound karena FYN paling suka bermain di tempat outbound (CWS IV.1:710 h.72). Dalam menyebutkan sesuatu yang dia kenal ada beberapa yang belum FYN ketahui tapi sebagian besar FYN sudah banyak mengetahui seperti yang dia suka pemadam kebakaran, atau mobil-mobilan (CWS IV.1:11-13 h.72). Ketika FYN ingin berinteraksi dengan orang lain seperti dengan teman sebayanya terkadang FYN dengan nada marahmarah, untuk menanyakan sesuatu FYN tidak mau menjawab dan terkadang mau menjawab (CWS IV.1:15-19 h.72).

Menurut Swarnadwitya (2012) Gadget adalah sebuah istilah yang berasal dari bahasa Inggris, yang artinya perangkat elektronik kecil yang memiliki fungsi khusus. Salah satu hal yang membedakan gadget dengan perangkat elektronik lainnya adalah unsur "kebaruan". Artinya, dari hari ke hari gadget selalu muncul dengan manyajikan teknologi terbaru yang membuat hidup manusia menjadi lebih praktis (Irawan, dkk, 2013, h. 29).

Komunikasi berarti suatu pertukaran pikiran dan perasaan. Pertukaran tersebut dapat dilaksanakan dengan setiap bentuk bahasa seperti: isyarat, ungkapan emosional, bicara, atau bahasa tulisan, tetapi komunikasi yang paling umum dan paling efektif dilakukan dengan bicara. Selama tahun-tahun awal masa kanak-kanak, tidak semua bicara digunakan untuk berkomunikasi. Pada waktu sedang bermain, anak seringkali berbicara dengan dirinya sendiri atau dengan mainannya. Meskipun demikian, pada saat minat untuk menjadi bagian dari kelompok sosial berkembang, mereka sebagian besar bicara untuk berkomunikasi dengan yang lain dan hanya sewaktu-waktu dengan yang lain dan hanya 
sewaktu-waktu berbicara terhadap diri mereka dan terhadap mainan mereka (Hurlock, 2013, h.176-177).

\section{Kesimpulan}

Berdasarkan hasil penelitian kualitatif dengan teknik observasi, wawancara, dan dokumentasi tentang dampak penggunaan gadget terhadap anak usia 4-5 tahun dapat diambil beberapa kesimpulan, bahwa penggunaan gadget adalah bermain game dan menonton film animasi serta hanya sedikit untuk media pembelajaran dan intensitas serta durasi pemakaiannya beragam tergantung dari pengawasan dan kontrol orang tua; Dampak dari penggunaan gadget dapat bersifat positif maupun negatif sesuai dari pengawasan dan arahan orang tua sebagai contoh yang baik bagi anak-anak di usia dini; Dampak positif dari penggunaan gadget lebih cenderung banyak dirasakan oleh orang tua yaitu lebih mudah untuk memantau dan mengatur pergaulan anak, sedangkan bagi anak di usia dini penggunaan gadget hanya untuk hiburan mereka semata dan memacu kegiatan belajar anak di usia dini; Dampak negatif dari penggunaan gadget adalah anak cenderung untuk individualis, susah bergaul dan apabila sudah kecanduan akan sangat sulit untuk dikontrol dari pemakaian gadget yang pada akhirnya otak anak-anak sulit berkembang karena selalu sering bermain game.

Tingginya intensitas dan durasi penggunaan gadget serta aplikasi yang dibuka kebanyakan game mebuat anak-anak usia dini sebaiknya dibatasi dalam pemakaian gadget karena tidak sesuai atau layak pada usianya jika terlalu banyak bermain game tanpa berinteraksi dengan orang lain atau teman sebayanya.

\section{Daftar Acuan}

Hurlock, Elizabeth. (2013). Perkembangan Anak. Jakarta: Erlangga.

Irawan, Jaka dan Leni. (2013). Pengaruh Kegunaan Gadget Terhadap Kemampuan Bersosialisasi Pada Remaja. Volume 08. No. 02. Fakultas Psikologi Universitas Islam: Riau.

Putra, Nusa, dkk. (2013). Penelitian Kualitatif PAUD. Jakarta: RajaGrafindo Persada.

Rozalia, Maya Ferdiana. (2017). Hubungan Intensitas Pemanfaatan Gadget Dengan Prestasi Belajar Siswa Kelas V Sekolah Dasar. Volume 5. No. 2. Malang.

Santosa, Elizabeth. (2015). Raising Children In Digital Era. Jakarta: PT Elex Media. 
Sugiyono. (2016). Metode Penelitian Pendidikan. Bandung: Alfabeta.

Susanto, A. (2011). Perkembangan Anak Usia Dini Pengantar Dalam Berbagai Aspeknya. Jakarta. Kencana Prenadamedia Grup.

Suyanto, Slamet. (2005). Dasar-Dasar Pendidikan Anak Usia Dini. Yogyakarta. Hikayat Publishing. 